\title{
Formulation and antimicrobial activity evaluation of a $0.2 \%$ chlorhexidine canine mouthwash with essential oils
}

\author{
Formulación y evaluación de la actividad antimicrobiana de \\ un enjuague bucal canino de clorhexidina al $2 \%$ y aceites \\ esenciales
}

Daniela González-Corrales', Lic; Tatiana Monge-Quirós', Lic; Marianela Chavarría-Rojas ${ }^{1,30}$, Lic; Norman Rojas-Campos², PhD; Wendy Cruz-Sibaja ${ }^{1}$, Lic; German Madrigal-Redondo ${ }^{1,3 *} \mathbb{C}$, MSc.

JOURNAL VITAE

School of Pharmaceutical and Food Sciences ISSN 0121-4004 | ISSNe 2145-2660 University of Antioquia Medellin, Colombia

Filliations

1 Profe1Escuela de Farmacia Universidad Latina de Costa Rica, San José, Costa Rica.

${ }^{2}$ Facultad de Microbiología, Universidad de Costa Rica, San José, Costa Rica.

${ }^{3}$ Facultad de Farmacia, Universidad de Costa Rica, San José, Costa Rica.

*Corresponding Germán Madrigal-Redondo german.madrigal@ucr.ac.cr

Received: 24 April 2020 Accepted: 25 January 2021 Published: 27 February 2021

\begin{abstract}
Background: Periodontal disease is the infection and inflammation of the gums, bones, and tissues involved in teeth support, and it is one of the most common diseases affecting pet dogs. Essential oils have shown antimicrobial activity against bacteria causing periodontal disease; therefore, they are considered potential therapeutic agents. Objectives: The main objective was to formulate and evaluate the antimicrobial activity of a $0.2 \%$ chlorhexidine canine mouthwash with essential oils. Methods: Three microemulsion formulations were obtained by constructing a pseudo-ternary phase diagram using the phase titration method. Different surfactant agents were evaluated, and hydrogenated castor oil was selected as the emulsifier agent. The antimicrobial activity of oregano essential oil (Origanum vulgare), thyme essential oil (Thymus vulgaris), and the three formulations were evaluated against Staphylococcus aureus, Streptococcus mutans, Streptococcus salivarius, and Escherichia coli. Results: Pure thyme and oregano essential oils showed higher antimicrobial activity than a $0,2 \%$ chlorhexidine solution. The formulations with essential oils plus chlorhexidine and chlorhexidine alone showed antimicrobial activity. The formulation containing only essential oils did not show antimicrobial activity. Conclusions: A canine mouthwash was formulated with chlorhexidine and thyme, and oregano essential oil. Based on the evaluation of antimicrobial activity, two of the proposed formulations could be a therapeutic option to reduce the risk and prevent periodontal disease in canines.
\end{abstract}

Keywords: periodontitis, microemulsion, oregano, thyme, chlorhexidine, essential oil. 


\section{RESUMEN}

Antecedentes: La enfermedad periodontal es la infección e inflamación de las encías, huesos y tejidos que brindan soporte a los dientes, es una de las enfermedades más comunes que afectan a los perros de compañía. Los aceites esenciales han mostrado actividad antimicrobiana contra las bacterias que causan la enfermedad periodontal; por lo tanto, son considerados como potenciales agentes terapéuticos. Objetivos: El objetivo principal de este trabajo fue formular y evaluar la actividad antimicrobiana de un colutorio canino de clorhexidina al 0,2\% con aceites esenciales. Métodos: Se obtuvo tres formulaciones en microemulsión mediante la construcción de un diagrama de fase pseudoternario por el método de titulación de fase. Se evaluaron diferentes tensioactivos y se seleccionó el aceite de ricino hidrogenado como agente emulsificante de la formulación. La actividad antimicrobiana del aceite esencial de orégano (Origanum vulgare), el aceite esencial de tomillo (Thymus vulgaris) y las tres formulaciones fue evaluada contra Staphylococcus aureus, Streptococcus mutans, Streptococcus salivarius y Escherichia coli. Resultados: Los aceites esenciales puros de tomillo y orégano mostraron una mayor actividad antimicrobiana que una solución de clorhexidina al $0,2 \%$. Las formulaciones con aceites esenciales más clorhexidina y únicamente clorhexidina mostraron actividad antimicrobiana. Mientras que la formulación que contiene solo aceites esenciales no mostró actividad antimicrobiana. Conclusión: Se formuló un enjuague bucal canino con clorhexidina y aceite esencial de tomillo y orégano. Según la evaluación de la actividad antimicrobiana, dos de las formulaciones propuestas podrían ser una opción terapéutica para disminuir el riesgo y prevenir la enfermedad periodontal en caninos.

Palabras clave: periodontitis, microemulsión, orégano, tomillo, clorhexidina, aceite esencial.

\section{INTRODUCTION}

Periodontal disease (PD) is one of the most common conditions that affect canines' oral cavity (1). Chronic $\mathrm{PD}$ is manifested by an overgrowth of anaerobic bacteria, mostly Gram-negative, at subgingival sites. It is described as the infection and inflammation of the gums, bones, and other tissues surrounding and teeth supporters. Temperature, humidity, and irregularities in the canine oral cavity facilitate the proliferation of the microorganisms, also, the lack of oral hygiene habits and constant cleaning. (2).

In Bogotá, Colombia, the Zoonosis Center has reported that nearly $64 \%$ of animals are affected by PD, and approximately $16 \%$ of those animals suffer both caries and PD (3). Moreover, in the US, PD prevalence is close to $80 \%$, and although prevalence rates vary between studies, PD is usually one of the most common diseases that affect canines (2).

As for PD treatment, some chemical agents have been used to help control bacterial plaque, for example, benzalkonium chloride, cetylpyridinium chloride, and essential oils that contain phenol, thymol, carvacrol, and eucalyptol. Chlorhexidine $(C L X)$ is also on the list of the most used chemical agents due to its antibacterial action against a wide range of aerobic and anaerobic bacteria (4). Besides, oregano essential oil (OEO) and thymus essential oil (TEO) have been associated with an important antimicrobial activity against Gram-positive and Gram-negative bacteria due to the presence of carvacrol, thymol, and $\alpha$-terpene (5).

Microemulsion preparations are a strategy for incorporating essential oils, such as OEO and TEO, into aqueous-based formulations. Microemulsions are colloidal dispersions of water, oil, and surfactant, which are transparent, monophasic, thermodynamically stable, with very low interfacial tension and low viscosity. Its formation is spontaneous, and the dispersed droplets have a diameter in the 1 to100 $\mathrm{nm}$ range, usually $10-50 \mathrm{~nm}(6,7)$.

In Costa Rica, the supply, availability, and access to canine oral hygiene products recommended as a preventive PD treatment is scarce. Therefore, the present study's main objective was to formulate and evaluate the antimicrobial activity of a $0.2 \%$ chlorhexidine canine mouthwash with oregano and thyme essential oils.

\section{MATERIALS AND METHODS}

\section{Essential oils}

Origanum vulgare essential oil (OEO) (lot 183554) and Thymus vulgaris essential oil (TEO) (lot 190219) were purchased from doTERRA International, San José, Costa Rica. According to the quality analysis certificates provided by the Aromatic Plant Research Center (https://aromaticplant.org/), the OEO contained $1.4 \%$ thymol and $72.1 \%$ carvacrol, and the TEO contained $59.1 \%$ thymol and $3.1 \%$ carvacrol.

The formulations were prepared as an essential oil mixture (EOM) composed of $85.7 \%$ OEO and $14.3 \%$ TEO.

\section{Emulsifier selection}

The EOM miscibility with different surfactant agents was evaluated because OEO and TEO's requiredHLB values were unknown. The evaluated surfactant agents were hydrogenated castor oil, Tween 80, 
Span 65, PEG 400, and PEG 400 combined with hydrogenated castor oil (50:50).

The surfactant agents were mixed with the EOM (1 part of EOM in 2 parts of surfactant). The selected emulsifier must guarantee the EOM complete miscibility; in this case, hydrogenated castor oil was the best surfactant option.

\section{Construction of pseudo-ternary phase diagram}

In the construction of the pseudo-ternary phase diagram, the EOM was considered the oil phase; distilled water was the aqueous phase; and the surfactant agent was the hydrogenated castor oil, based on the emulsifier selection results.

The surfactant and aqueous phase were mixed in a specific ratio (1:99 to 10:90) in different vials. The EOM was added in a fixed proportion to guarantee OEO and TEO's minimum inhibitory concentration. Table 1 data was used to construct the ternary phase diagram.

The pseudo-ternary phase diagram mixtures were evaluated by visual inspection, and the nonopaque mixtures were selected as the possible microemulsion formulation. In the selection among non-opaque mixtures, the lowest amount of surfactant added was considered.

Table 1. Composition of the pseudo-ternary phase diagram mixtures.

\begin{tabular}{cccc}
\hline Mixture & EOM (\%) & Surfactant (\%) & Water (\%) \\
\hline S1 & 0.4 & 1.2 & 98.4 \\
S2 & 0.4 & 2.1 & 97.5 \\
S3 & 0.4 & 3.1 & 96.5 \\
S4 & 0.4 & 4.1 & 95.5 \\
S5 & 0.4 & 5.2 & 94.5 \\
S6 & 0.4 & 6.5 & 93.1 \\
S7 & 0.4 & 7.2 & 92.4 \\
S8 & 0.4 & 8.2 & 91.4 \\
S9 & 0.4 & 9.3 & 90.3 \\
S10 & 0.4 & 10.4 & 89.2 \\
\hline
\end{tabular}

"The surfactant agent was the hydrogenated castor oil, based on the emulsifier selection results.

\section{Preparation of microemulsion formulations}

The mixture S10 from the pseudo-ternary phase diagram was selected as the starting point for the canine mouthwash formulation. It was optimized to reach the desirable characteristics by adding and incorporating different excipients such as preservatives, viscosity enhancers, $\mathrm{pH}$ adjusting agents, and flavoring agents. Preservatives (parabens) were added to avoid microbiological contamination, sodium carboxymethylcellulose (CMC) used as a viscosity enhancer, and $\mathrm{NaOH}$ as $\mathrm{pH}$-adjusting agent. The flavoring agent was added to improve the formulations' organoleptic properties because it is designed to be administered by the oral route. In addition to the EOM, chlorhexidine (CLX) was added to the formulations as an active ingredient.

\section{Evaluation of the antimicrobial activity of essential oils and formulations}

The antimicrobial activity evaluation of essential oils and formulations was carried out in the Microbiology Faculty at the Universidad de Costa Rica. The antimicrobial activity was determined by the disk diffusion test (8).

The strains Staphylococcus aureus ATCC 25923, Streptococcus mutans ATCC 35668, S. salivarius ATCC 13419, and Escherichia coli ATCC 25922 were used for the antimicrobial activity evaluation. Chlorhexidine $0.2 \%$ (distilled water as solvent) was a positive control (PC), and sterile water was the negative control (NC).

In the first instance, the OEO, TEO, and EOM were evaluated. The essential oils alone or in combination were filtered through a $0.22 \mu \mathrm{m}$ membrane filter and, by triplicate, $40 \mu \mathrm{L}$ of each sample was placed in $6 \mathrm{~mm}$ diameter wells. Blood agar plates were incubated at $37{ }^{\circ} \mathrm{C}$ for 48 hours, and halos of inhibition were measured.

After the antimicrobial activity confirmation of OEO, TEO, and EOM, the vehicle (formulation without active ingredient) and the formulations in Table 2 were evaluated by the method described before using the mentioned strains. All the antimicrobial activity results are expressed as mean \pm SEM.

\section{Statistical analysis}

Statistical analysis was performed using the program GraphPad Prism 8.3.1. Analysis of variance (ANOVA) and Tukey tests was used for statistics. A significance level of 0.05 was considered statistically significant. 


\section{RESULTS}

\section{Emulsifier selection}

The surfactants hydrogenated castor oil, Tween 80, Span 65, PEG 400, and PEG 400 combined with hydrogenated castor oil (50:50) were evaluated. Mixing EOM with hydrogenated castor oil allowed the complete miscibility between both components. The final solution was clear, and a one-phase system was observed. Mixing EOM with Tween 80, Span 65, PEG 400, or PEG 400 combined with hydrogenated castor oil (50:50) resulted in an opaque mixture. Also, after 4 hours resting period, the mixtures formed a two phases system.

\section{Construction of pseudo-ternary phase diagram}

The pseudo-ternary phase diagram is shown in Figure 1. Mixtures S8, S9, and S10 formed a clear microemulsion with low agitation energy. All the samples were maintained at room temperature for 48 hours, and after the resting period mixtures, S1S7 developed a two-phase system, while mixtures S8-S10 remained in a microemulsion system.

\section{Preparation of microemulsion formulations}

The mixture S10 from the pseudo-ternary phase diagram construction was the starting point formulation. The chlorhexidine (CLX) was added to S10 in an amount equivalent to $0.2 \%$ of the total formulation weight, while EOM concentration was $0.4 \%$, the needed concentration to guarantee the minimum inhibitory concentration of OEO and TEO.

Preservatives, pH-adjusting agents, viscosity enhancers, and flavoring agents were included in the initial microemulsion to formulate a canine mouthwash with the right organoleptic properties to be administered by the oral route. The different microemulsion formulations were developed to adjust the viscosity, $\mathrm{pH}$ value, and flavor. Sodium carboxymethylcellulose (CMC) was used as a viscosity enhancer and as a mucoadhesive agent to increase the oral cavity's product permanence. The formulations' acidity was adjusted to $\mathrm{pH} 8.55$ because they were designed to be applied in the canine oral cavity, ranging between 8.50 and 8.65. Finally, the preservatives used in formulations were parabens, which are active in a wide $\mathrm{pH}$ range.

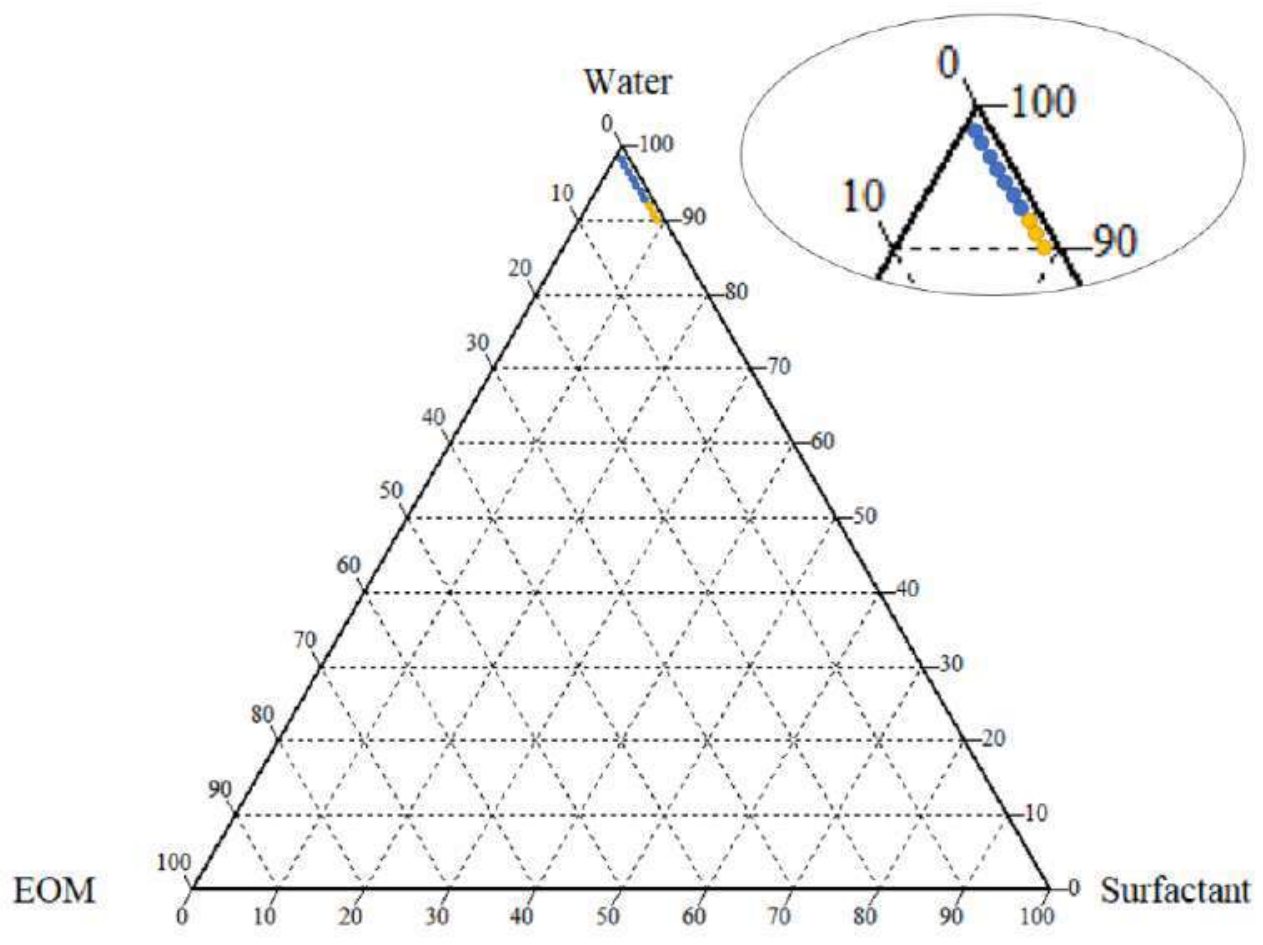

Figure 1. Pseudo-ternary phase diagram of water - EOM - surfactant (hydrogenated castor oil). The blue dots represent a two-liquid phases mixture, and the yellow dots represent a microemulsion system. EOM: Essential oil mixture. 
Three possible formulations were obtained (Table 2). The differences between those formulations were the active pharmaceutical ingredients: F1 only contained the EOM, F2 contained CLX $0.2 \%$, and F3 contained EOM and CLX $0.2 \%$.

Table 2. Composition of the possible mouthwash formulations.

\begin{tabular}{|c|c|c|c|c|c|c|c|c|}
\hline \multirow{2}{*}{ Formulation } & \multirow[b]{2}{*}{$\begin{array}{l}\text { Surfactant (hydrogenated } \\
\text { castor oil) }\end{array}$} & \multirow[b]{2}{*}{ CMC } & \multicolumn{3}{|c|}{ Excipients (\% w/w) } & \multirow[b]{2}{*}{ Water } & \multicolumn{2}{|c|}{$\begin{array}{c}\text { Active } \\
\text { ingredients } \\
(\% \mathbf{w} / \mathbf{w})\end{array}$} \\
\hline & & & $\begin{array}{l}\text { Preservatives } \\
\text { (parabens) }\end{array}$ & $\mathrm{NaOH} 1 \mathrm{M}$ & $\begin{array}{l}\text { Flavoring } \\
\text { agent }\end{array}$ & & EOM & CLX \\
\hline F1 & 10,4 & 0,1 & 0,1 & 0,4 & 4,2 & q.s. 100 & 0,4 & - \\
\hline F2 & 10,4 & 0,1 & 0,1 & 0,4 & 3,0 & q.s. 100 & - & 0,2 \\
\hline F3 & 10,4 & 0,1 & 0,1 & 0,4 & 4,2 & q.s. 100 & 0,4 & 0,2 \\
\hline Vehicle & 10,4 & 0,1 & 0,1 & 0,4 & 4,2 & q.s. 100 & - & - \\
\hline
\end{tabular}

\section{Antimicrobial activity evaluation of essential oils and formulations}

The antimicrobial activity evaluation of OEO, TEO, and EOM is shown in Figure 2. The bacterial growth inhibitory effect of essential oils, alone and in combination, was higher than the NC, thus demonstrating the OEO, TEO, and EOM's

antimicrobial activity. Also, the essential oils' antimicrobial activity was more elevated than CLX $0.2 \%$, the PC. OEO and TEO were evaluated alone and combined due to the possibility of a synergic effect between them; however, it was not observed.
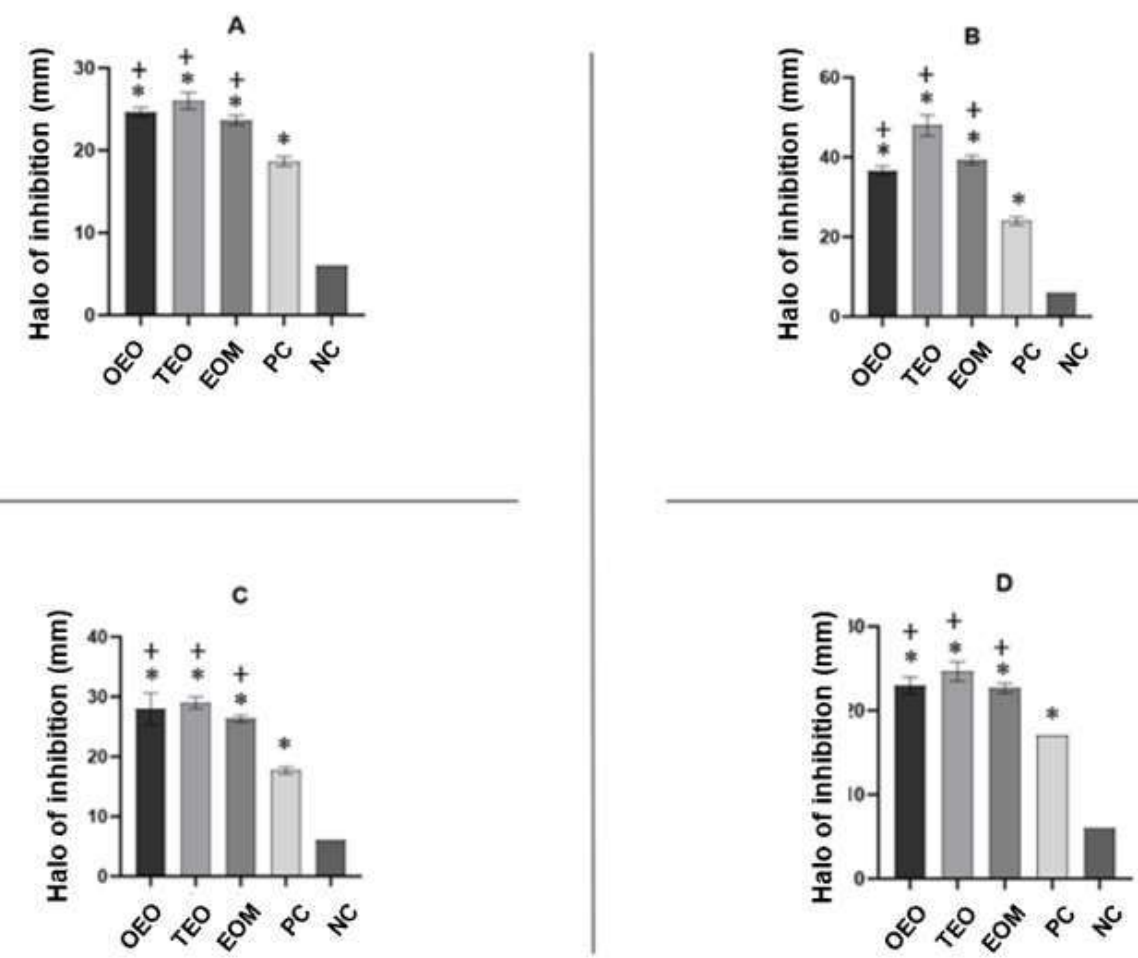

Figure 2. Evaluation of the antimicrobial activity of essential oils. (A) $S$. aureus, (B) $S$. mutans, (C) $S$. salivarius, (D) E. coli. * $p<0.05$ compared to $\mathrm{NC} ;+\mathrm{p}<0.05$ compared to PC. Veh: vehicle (formulation without active ingredient), F1: Formulation 1 (essential oil mixture as the active ingredient), F2: Formulation 2 (chlorhexidine as the active ingredient), F3: Formulation 3 (essential oil mixture plus chlorhexidine as active ingredients), PC: Positive control, NC: Negative control. 
The antimicrobial activity evaluation of vehicle and microemulsion formulations is shown in Figure 3. The bacterial growth inhibitory effect of vehicle and F1 was zero, the same value that NC. The antimicrobial activity of F2 and F3 was lower than PC but higher than NC. There is a possibility that the formulation excipients decrease the antimicrobial activity of CLX and EOM.
A

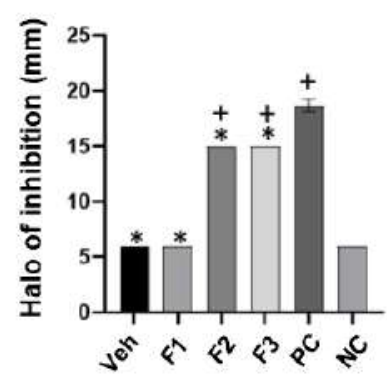

C

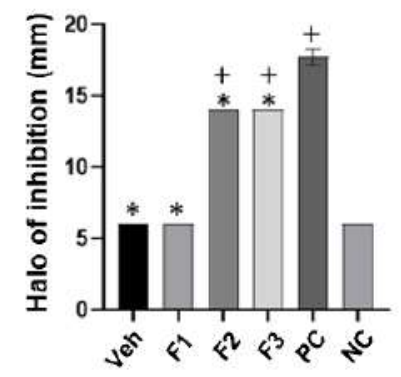

B

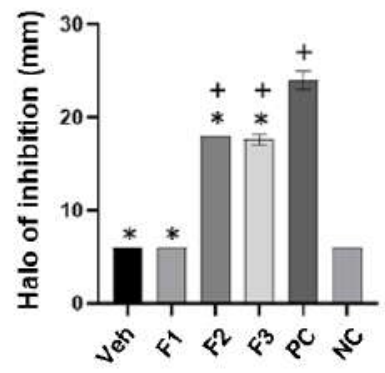

D

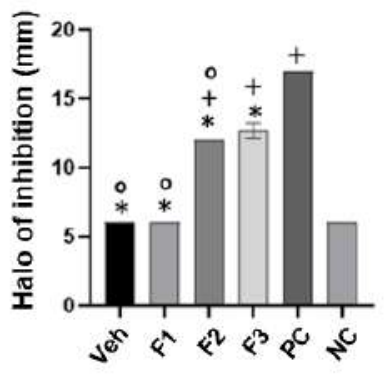

Figure 3. Evaluation of the antimicrobial activity of vehicle and microemulsion formulations. (A) S. aureus, (B) S. mutans, (C) S. salivarius, (D) E. coli. * $\mathrm{p}<0.05$ compared to $\mathrm{PC} ;+\mathrm{p}<0.05$ compared to NC; ${ }^{\circ} \mathrm{p}<0.05$ compared to F3. Veh: vehicle (formulation without active ingredient), F1: Formulation 1 (essential oil mixture as the active ingredient), F2: Formulation 2 (chlorhexidine as the active ingredient), F3: Formulation 3 (essential oil mixture plus chlorhexidine as active ingredients), PC: Positive control, NC: Negative control.

\section{DISCUSSION}

A canine mouthwash was developed as a microemulsion formulation using chlorhexidine (CLX), thymus essential oil (TEO), and oregano essential oil (OEO) as active pharmaceutical ingredients. CLX is one of the most used chemical agents recommended for periodontal disease prevention, and it has been used as an antiseptic in mouthwashes, toothpaste, and oral hygiene products $(9,10,11)$. This agent reduces biofilm formation by altering bacteria's adhesion to teeth and gingival tissues and disrupts the bacterial cell membrane increasing cell permeability (4).

The main components of OEO and TEO are carvacrol, thymol, and $\alpha$-terpene (5). Carvacrol is a non-toxic monoterpene, widely studied for its pharmacological properties such as antibacterial and antifungal activities (12). Thymol and carvacrol mechanisms of action are similar. In Gram-negative bacteria, the cell permeability increases, and the membrane stability decreases due to the membrane disruption and lipopolysaccharides release. In Gram-positive bacteria, thymol binds to membrane protein hydrophobic residues by hydrogen bonding, increasing the cell permeability (13).

OEO, TEO, and CLX have been formulated as microemulsions to treat different diseases (14, $15,16,17)$. In this investigation, we propose a canine mouthwash formulation as a microemulsion system. Microemulsions are dispersions of water, oil, and surfactants that are monophasic systems, thermodynamically stable with a long shelf life, low cost, low viscosity, and clear appearance. One of the major advantages of microemulsions is their 
formation process; it is spontaneous and selfassembly, reducing production cost and time $(6,7)$.

The canine mouthwash formulation was developed as a stepwise process. In the first place, the essential oils' miscibility with different surfactants was evaluated since the required-HLB value of essential oils was unknown. This study suggests that the best emulsifier agent for the EOM and the mouthwash formulation was hydrogenated castor oil because it guarantees the EOM and CLX complete miscibility and stability. Besides, hydrogenated castor oil is a low cost and low toxicity surfactant agent, desirable properties for excipients selection (18).

Once hydrogenated castor oil was selected as an emulsifier agent, a ternary phase diagram was constructed. Ternary phase diagrams offer information about the thermodynamically stable phases of a three-component system under specific conditions (19) and are considered a tool in microemulsion formulations development $(14,15$, $16,17,20)$. In this case, the EOM was the oil phase, distilled water was the aqueous phase, and the surfactant agent was the hydrogenated castor oil. Figure 1 shows three one-phase mixtures with a clear and non-opaque appearance; the microemulsion's spontaneous formation was observed during the mixing process. Large amounts of energy were not required, only a slight agitation to facilitate the process. For this reason, those mixtures were considered microemulsions $(6,14)$. Microemulsion systems allow the essential oils' complete dispersion and can be used as a stable and low-cost formulation strategy $(14,15,17)$.

The mouthwash formulations were developed using the ternary phase diagram's microemulsions, and the CLX inclusion was the defining step process to select the best microemulsion mixture for the mouthwash formulation. Although three microemulsion mixtures were obtained (Figure 1), only S10 allows the CLX $0.2 \%$ addition. The formulation included different excipients, such as preservatives, $\mathrm{pH}$-adjusting agents, viscosity enhancers, and flavoring agents. The objective was to improve and optimize canine mouthwash organoleptic properties according to the canine oral cavity requirements and characteristics (18).

The antimicrobial activity evaluation of mouthwash formulations indicates that despite EOM is related to a higher bacterial growth inhibitory effect than CLX $0.2 \%$ (Figure 2), in the formulation containing EOM (F1), the inhibition of bacterial growth disappears (Figure 3). Usually, essential oils' activity in microemulsion systems can be affected by the oil phase composition, and emulsifier quantity and structure (14); and taking into consideration that the essential oils final concentration was the minimum inhibitory concentration reported in the literature, i.e., $0.690 \mathrm{mg} / \mathrm{mL}$ for OEO and 0.062 to $0.500 \mathrm{mg} /$ $\mathrm{mL}$ for TEO (21, 22). Incompatibilities between active ingredients or the use of sub-therapeutic concentrations of essential oils may reduce the antimicrobial activity (23). Another possible reason for the absence of antibacterial activity in F1 could be the formulation $\mathrm{pH}$ because TEO's effect is more significant at lower $\mathrm{pH}$ values. Some of the TEO components are not dissociated in acid media, facilitating bacterial membranes' disruption (13).

On the other hand, F2 containing 0.2\% CLX and excipients showed a lower inhibition of bacterial growth than the positive control $(0.2 \% \mathrm{CLX}$ in water). That difference in the antimicrobial activity might be to the presence of a nonionic surfactant in the formulation since it reduces the CLX activity (24).

Despite F2 and F3 antimicrobial activity decrease compared to the positive control, results suggest that both formulations are an alternative to decrease the bacterial growth of the main bacteria associated with periodontal disease in dogs. A strategy to improve the formulation could be increasing the concentrations of the essential oils.

\section{CONCLUSIONS}

Two formulations of a chlorhexidine canine mouthwash were developed in this study. Based on the antimicrobial activity evaluation, both formulations could be a therapeutic option to decrease the risk and prevent periodontal disease in dogs.

Conflict of interest: The authors reported no potential conflicts of interest.

\section{Acknowledgments: NA}

\section{AUTHOR CONTRIBUTIONS:}

González-Corrales Daniela (Lic) and Monge-Quirós Tatiana (Lic) performed the experiments of this work, Rojas-Campos Norman (PhD) supervised antimicrobial experiments, Cruz-Sibaja Wendy (Lic), Chavarría-Rojas Marianela (Lic) and MadrigalRedondo German (MSc) direct the experiments, the formulation process, and the analysis. 


\section{REFERENCES}

1. Hennet P. Nutrición y salud oral en el perro. [Internet] Madrid, Spain: Royal Canin. 2006 [Consulted 28 July of 2020]. Available from http://campusveterinariarc.com/docs/enciclopedia-denutricion-canina/Cap-12-Nutricion-y-salud-oral-en-el-perro.pdf

2. Stella JL, Bauer A E, Croney CC. A cross-sectional study to estimate prevalence of periodontal disease in a population of dogs (Canis familiaris) in commercial breeding facilities in Indiana and Illinois. PLoS ONE. 2018; 13(1): 1-14. DOI: https://doi.org/10.1371/journal. pone.0191395

3. Rubiano D, Rojas D, Almansa J. Frecuencia de Enfermedad periodontal y caries en caninos del centro de Zoonosis de Bogotá Revista Nacional de Odontología. 2012; 8(15): 21-29.

4. Platt C, Tosta E, Machado M. Uso de los diferentes agentes químicos para el control de la placa bacteriana como coadyuvantes en la prevención de las enfermedades gingivales. Rev ODOUS Científica. 2004; 10(4): 5-9.

5. Zhou R, Wu J, Zhang L, Liu L, Casper DP, Jiao T, ... Gong X Effects of oregano essential oil on the ruminal $\mathrm{pH}$ and microbial population of sheep. Plos One. 2019; 14(5): e0217054. DOI: https:// doi.org/10.1371/journal.pone.0217054

6. Kale SN, Deore SL. Emulsion Micro Emulsion and Nano Emulsion : A Review. Sys Rev Pharm. 2017; 8(1): 39-47. DOI: https://doi. org/10.5530/srp.2017.1.8

7. Nastiti CM, Ponto T, Abd E, Grice JE, Benson HAE, Roberts MS Topical Nano and Microemulsions for Skin Delivery. Pharmaceutics. 2017; 9(37). DOI: https://doi.org/10.3390/pharmaceutics9040037

8. Soares $H$, Soares $L$, Bernardo $M$. In vitro study of the effect of an essential oil and a delmopinol mouth rinse on dental plaque bacteria. Indian J Dent Res. 2017; 27(6): 648. DOI: https://doi. org/10.4103/0970-9290.199602

9. Matuq Badri S, Hesham Felemban E, Kamel Alnajjar G, Monawar Alotaibi F, Talin Aljahdali S, Ahmed Maher Y, Fathi A. Effectiveness of probiotic lozenges and chlorhexidine mouthwash on plaque index, salivary $\mathrm{pH}$, and Streptococcus mutans count among school chindren in Makkah, Saudi Arabia. Saudi Dental Journal. 2020 Article In Press. DOI: https://doi.org/10.1016/j.sdentj.2020.05.006

10. de Oliveira Carvalho I, Aparecida Purgato G, Soares Píccolo M, Ramos Pizziolo V, Ribeiro Coelho R, Diaz-Muñoz G, Nogeira Diaz MA. In vitro anticarcinogenic and antibiofilm activities of toothpastes formulated with essential oils. Arch Oral Biol. 2020; 117. DOI: https://doi.org/10.1016/j.archoralbio.2020.104834

11. Seyed Hashemi M, Hashem Hashempur M, Hassan Lotfi M, Hemat H, Mousavi Z, Emtiazy M, Vaziri F. The efficacy of asafoetida (Ferula assa-foetida oleo-gum resin) versus chlorhexidine gluconate mouthwash on dental plaque and gingivitis: A randomized doubleblind controlled trial. Eur J Integr Med. 2019; 29. DOI: https://doi. org/10.1016/j.eujim.2019.100929

12. Vinciguerra V, Rojas F, Tedesco V, Giusiano G, Angiolella L. Chemical characterization and antifungal activity of Origanum vulgare, Thymus vulgaris essential oils and carvacrol against Malassezia furfur. Nat Prod Res. 2018: 6419: 1-5. DOI: https://doi. org/10.1080/14786419.2018.1468325
13. García RM, Palou E. Mecanismo de acción antimicrobiana de timol y carvacrol sobre microorganismos de interés en alimentos. Temas Selectos de Ingeniería de Alimentos. 2008; 2(2): 41-51.

14. Ma $Q$, Davidson $M$, Zhong $Q$. Antimicrobial properties of microemulsions formulated with essential oils, soybean oil, and Tween 80. Int J Food Microbiol. 2016; 226: 20 - 25. DOI: https:// doi.org/10.1016/j.jifoodmicro.2016.03.011

15. Menezes de Sá A, dos Santos EW, Santana MH, Santos A, de Araujo GR, Santana DG, Arguelho M, e Silva AM, Correa CB, Nunes R, Sarmento VH, Lira AA. Evaluation of the incorporation of essential oils in microemulsions as a promising formulation in the inhibition of tyrosinase. Ind Crops Prod. 2020; 154. DOI: https:// doi.org/10.1016/j.indcrop.2020.112654

16. Lucia A and Guzman E. Emulsions containing essential oils, their components or volatile semiochemicals as promising tools for insect pest and pathogen management. Colloid Interface Sci. 2021; 287. DOI: https://doi.org/10.1016/j.cis.2020.102330

17. Laothaweerungsawat N, Naimkhum W, Anuchapreeda S, Sirithunyalug J, Chaiyana W. Transdermal delivery enhancement of carvacrol from Origanum vulgare $L$. essential oil by microemulsion. Int. J. Pharm. 2020; 579. DOl: https://doi.org/10.1016/j. ijpharm.2020.119052

18. Aulton ME, Taylor K. Aulton's Pharmaceutics: The Design and Manufacture of Medicines. 4 ed. London, England: Elsevier; 2013.

19. Pye C, Imperial MA, Elson C, Himmelman ML, White JA, Lin F. Investigation of the Ternary Phase Diagram of Water - Propan2-ol - Sodium Chloride: A Laboratory Experiment. J. Chem. Educ. 2018; 95 (8): 1398 - 1401. DOI: https://doi.org/10.1021/acs. jchemed.8b00242

20. Pathan IB, Dwivedi R, Ambekar W. Formulation and evaluation of ketoprofen loaded chitosan nanogel for pain management Ex vivo and in vivo study. Ars Pharm. 2019; 60(2): 101 - 108. DOI: https:// doi.org/10.30827/ars.v60i2.8563

21. Ahmad A, Van Vuuren S, Viljoen A. Unravelling the complex antimicrobial interactions of essential oils - the case of Thymus vulgaris (Thyme). Molecules. 2014;19(3):2896-2910. DOI: https:// doi.org/10.3390/molecules19032896

22. Busatta C, Mossi AJ, Rodrigues MRA, Cansian RL, De Oliveira JV. Evaluation of Origanum vulgare essential oil as antimicrobial agent in sausage. Braz. J. Microbiol. 2007; 38(4): 610-616. DOI: https://doi.org/10.1590/S1517-83822007000400006

23. Narang AS, Mantri RV, Raghavan KS. Excipient compatibility and functionality. In: Qiu Y, Chen Y, Zhang G, Yu L, Mantri R, editors. Developing Solid Oral Dosage Forms. 2 ed. London: Academic Press; 2017.

24. Maya J J, Ruiz SJ, Pacheco R, Valderrama SL, Villegas MV. Papel de la clorhexidina en la prevención de las infecciones asociadas a la atención en salud. Infectio. 2011; 15(2): 98-107. DOI: https:// doi.org/10.1016/S0123-9392(11)70749-4 